\title{
In vitro Efficacy of Antibacterial Proteins from Haemolymph of Silkworm Breeds against Bacterial Pathogens of Mulberry Silkworm, Bombyx mori L.
}

\author{
S. Manimegalai ${ }^{1}$, B. Bebitha ${ }^{2}$ and P.Mohanraj ${ }^{3 *}$ \\ ${ }^{1}$ Department of Agricultural Entomology, Tamil Nadu Agricultural University, \\ Coimbatore-3, India \\ ${ }^{3}$ Department of Sericulture, Forest College and Research Institute, Mettupalayam, India \\ *Corresponding author
}

\begin{tabular}{|c|c|}
\hline & A B S T RA C T \\
\hline & Antibacterial activity of proteins eluted from immunized haemolymph collected from \\
\hline $\begin{array}{l}\text { Key w or d s } \\
\text { Bombyx mori, } \\
\text { Antibacterial, } \\
\text { Proteins, } \\
\text { Mulberry, Bacillus } \\
\text { thuringiensis. }\end{array}$ & $\begin{array}{l}\text { were studied against bacterial pathogens. The breeds were immunized with bacterial } \\
\text { pathogens, Escherichia coli }\left(\mathrm{K}^{\mathrm{R}} \text { strain), Bacillus thuringiensis and Staphylococcus }\right. \\
\text { aureus. In vitro efficacy of purified antibacterial proteins from breeds of B.mori against } \\
\text { E.coli, S. aureus and B. thuringiensis revealed that among the ten fractions of } \\
\text { antibacterial proteins eluted from B.mori breeds, ninth fraction@ } 200 \mu 1 \text { showed higher } \\
\text { antibacterial activity in Rong daizo }(3.01 \mathrm{~cm}, 3.10 \mathrm{~cm} \text { and } 1.82 \mathrm{~cm})(2.71 \mathrm{~cm}, 3.01 \mathrm{~cm} \text { and } \\
1.60 \mathrm{~cm}), \text { CSR } 2(2.98 \mathrm{~cm}, 3.05 \mathrm{~cm} \text { and } 1.81 \mathrm{~cm}) \text { and double hybrid }(2.89 \mathrm{~cm}, 2.98 \mathrm{~cm}\end{array}$ \\
\hline Article Info & and $1.79 \mathrm{~cm}$ ) against E.coli, S. aureus and B. thuringiensis (Table 1,2\&3).Lesser \\
\hline $\begin{array}{l}\text { Accepted: } \\
\text { 20 February } 2017 \\
\text { Available Online: } \\
10 \text { March } 2017\end{array}$ & $\begin{array}{l}(2.71 \mathrm{~cm}, 3.01 \text { and } 1.60 \mathrm{~cm}) \text { followed by CSR2 }(2.68 \mathrm{~cm}, 2.98 \mathrm{~cm} \text { and } 1.59 \mathrm{~cm}) \text { and DH } \\
(2.69 \mathrm{~cm}, 2.96 \mathrm{~cm} \text { and } 1.54 \mathrm{~cm}) \text { respectively. Standard antibiotic streptomycin sulphate @ } \\
200 \mu \mathrm{l} \text { concentration produced the inhibition zone of } 7.12 \mathrm{~cm}, 8.12 \mathrm{~cm} \text { and } 6.32 \mathrm{~cm} \text {. } \\
\text { Purified antibacterial protein fractions showed higher antibacterial activity against gram } \\
\text { negative E.coli and gram positive S.aureus and low activity against B.thuringiensis. }\end{array}$ \\
\hline
\end{tabular}

\section{Introduction}

Several self-defense proteins have been isolated from the silkworm, Bombyx mori and their amino acid sequences determined. These proteins include novel antibacterial proteins designated lebocin and moricin, Among the various defense mechanisms in B.mori, humoral responses involved phenoloxidase and immune proteins such as antimicrobial proteins (AMPs), lysozyme and lectins. In response to microbial infection, AMPs and lysozyme are rapidly produced primarily in the fat body and haemocytes and subsequently secreted into the haemolymph to eliminate invading pathogens (Tanaka and Yamakawa, 2011). The induced antibacterial protein of silkworm have shown antibacterial effect against a wide variety of gram positive bacteria such as Agrobacterium tumefaciens, Enterobacter cloacae, Escherichia coli, Serratia marcescens and gram negative bacteria such as Micrococcus ureae, Cornybacterium equi and Staphylococcus aureus (Morishima et al.,1988). Upon bacterial infection, antibacterial proteins, 
lectins and lysozymes rapidly appear in the haemolymph (Boman and Hultmark, 1987). Cecropins are family of highly potent bactericidal peptides with 35-37 amino acid residues (Boman et al., 1991). B.mori was found to contain eleven types of cecropin ( $\mathrm{Tu}$ et al., 1989; Morishima et al.,1990; Hara et al., 1994).

Present study investigated the antibacterial activity of haemolymph of B.mori by inhibition zone assay. The haemolymph proteins obtained from Sephadex G-100 column $(55 \times 1.5 \mathrm{~cm})$ were used for SDSPAGE analysis. Among the ten fractions isolated, fractions seven and nine were found to have antibacterial activity and were compared with streptomycin sulphate. The fractions isolated from infected breeds of B.mori were more effective at higher dose of $200 \mu \mathrm{l}$ compared to $100 \mu \mathrm{l}$ against E.coli, S.aureus and Bacillus thuringiensis in Rong Daizo (3.01 $\pm 0.042,3.10 \pm 0.04$ and 1.82 \pm $0.051)$, Double hybrid $(2.89 \pm 0.732,2.98 \pm$ 0.750 and1.79 \pm 0.445) and CSR2 $(2.98 \pm 0.748, \quad 3.05 \pm 0.764$ and $1.81 \pm 0.448)$ respectively.

\section{Materials and Methods}

\section{Purification of induced antibacterial protein from silkworm}

\section{Collection of haemolymph}

Silkworm breeds, Rong Daizo, CSR 2 and double hybrid were reared on mulberry leaves under ambient conditions as per the standard rearing method (Krishnaswami,1978). Bacterial pathogens, Escherichia coli $\left(\mathrm{K}^{\mathrm{R}}\right.$ strain), Bacillus thuringiensis and Staphylococcus aureus were used for antibacterial assay. Three day old fifth instar larvae were fed with $10 \mu \mathrm{l}$ suspension of $\log$ phase E.coli at $1 \times 10^{3}$ cells $/ \mathrm{ml}$ by spraying on mulberry leaves. Haemolymph samples were collected after $24 \mathrm{~h}$ of treatment into pre cooled tubes containing one per cent phenylthiourea, centrifuged at $10000 \mathrm{rpm}$ at $4^{\circ} \mathrm{C}$ for $10 \mathrm{~min}$ and stored at $-20^{\circ} \mathrm{C}$. Haemolymph from untreated larvae served as control.

\section{Purification of antibacterial protien}

Step I: Haemolymph was collected from 30 immunized larvae at $24 \mathrm{~h}$ after treatment and diluted five times in $0.3 \mathrm{M}$ ammonium acetate maintaining a $\mathrm{pH}$ of 7.0 and applied to a Sephadex G-75 (20x1cm) column equilibrated in $0.3 \mathrm{M}$ ammonium acetate at a flow rate of $10 \mathrm{ml} / \mathrm{hr}$. The column was washed several times with $0.3 \mathrm{M}$ ammonium acetate. The bound proteins were eluted stepwise using the same buffer and the obtained fractions were observed at $280 \mathrm{~nm}$ (Abraham et al.,1995).

Step II: Antibacterial proteins obtained from the step I was applied onto a Sephadex G-100 column $(55 \times 1.5 \mathrm{~cm})$ in $0.1 \mathrm{M}$ phosphate buffer $(\mathrm{pH} 7.0)$ at a flow rate of $18 \mathrm{ml} / \mathrm{hr}$ and eluted fractions were observed in UVspectrophotometer at $280 \mathrm{~nm}$. Haemolymph fractions were also collected from larvae treated with saline to compare the antibacterial protein induction with response to oral administration of bacteria. The fractions collected from step I and step II were tested for its antibacterial activity.

Antibacterial activity was assayed by measuring the zone of growth inhibition on thin agar plates with E.coli, S.aureus and B.thuringiensis. Serially diluted control and immunized protein samples were applied into wells on a thin agar plate seeded with bacteria. The zone of inhibition was measured and compared to that of control protein. Extracted fractions were compared with the standard antibiotic, Streptomycin sulphate. 


\section{Results and Discussion}

Studies on in vitro efficacy of purified antibacterial proteins from Rong daizo, CSR2 and double hybrid of B.mori against E.coli, S. aureus and $B$. thuringiensis revealed that among the ten fractions of antibacterial proteins eluted from B.mori breeds, ninth

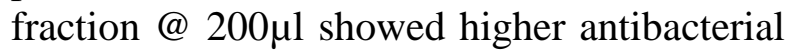
activity in Rong daizo $(3.01 \mathrm{~cm}, 3.10 \mathrm{~cm}$ and $1.82 \mathrm{~cm})(2.71 \mathrm{~cm}, 3.01 \mathrm{~cm}$ and $1.60 \mathrm{~cm})$, CSR2 $(2.98 \mathrm{~cm}, 3.05 \mathrm{~cm}$ and $1.81 \mathrm{~cm})$ and double hybrid ( $2.89 \mathrm{~cm}, 2.98 \mathrm{~cm}$ and 1.79 $\mathrm{cm}$ ) against E.coli, S. aureus and $B$. thuringiensis (Table 1,2\&3)

Lesser inhibitory activity was recorded in seventh fraction compared to ninth fraction @ $200 \mu 1$ concentration of Rong daizo $(2.71 \mathrm{~cm}$, 3.01 and $1.60 \mathrm{~cm})$ followed by CSR2 (2.68 $\mathrm{cm}, 2.98 \mathrm{~cm}$ and $1.59 \mathrm{~cm})$ and $\mathrm{DH}(2.69 \mathrm{~cm}$, $2.96 \mathrm{~cm}$ and $1.54 \mathrm{~cm}$ ) respectively. Standard antibiotic streptomycin sulphate @ $200 \mu 1$ concentration produced the inhibition zone of $7.12 \mathrm{~cm}, 8.12 \mathrm{~cm}$ and $6.32 \mathrm{~cm}$. The present results are in conformity with the findings of (Hoffmann and Hetru,1992.) who reported that protein purified from different insect sources are reported to attack only grampositive bacteria..

Antibacterial activity of obtained proteins also corroborated with the findings of Morishima et al. (1988) who reported that purified antibacterial protein fractions showed higher antibacterial activity against gram negative E.coli and gram positive S.aureus and low activity against B.thuringiensis. which is well supported by the present study.

Table.1 In vitro efficacy of purified antibacterial proteins (ABP) from Rong Daizo against bacterial pathogens

\begin{tabular}{|c|c|c|c|}
\hline \multirow[t]{2}{*}{ Treatments } & \multicolumn{3}{|c|}{ Zone of inhibition (cm \pm S.D.)* by ABP from Rong Daizo } \\
\hline & E.coli & S.aureus & B.thuringiensis \\
\hline \multicolumn{4}{|c|}{ ABP eluted fractions $(\mu \mathrm{l})$} \\
\hline \multicolumn{4}{|l|}{ A1. Fraction -7} \\
\hline i. 100 & $2.30 \pm 0.032$ & $2.90 \pm 0.013$ & $1.41 \pm 0.033$ \\
\hline ii. 200 & $2.71 \pm 0.008$ & $3.01 \pm 0.014$ & $1.60 \pm 0.012$ \\
\hline \multicolumn{4}{|l|}{ A2. Fraction -9 } \\
\hline i. 100 & $2.81 \pm 0.014$ & $2.92 \pm 0.008$ & $1.55 \pm 0.008$ \\
\hline ii. 200 & $3.01 \pm 0.042$ & $3.10 \pm 0.04$ & $1.82 \pm 0.051$ \\
\hline \multicolumn{4}{|l|}{$\begin{array}{l}\text { B. Streptomycin } \\
\text { Sulphate }\end{array}$} \\
\hline i. 100 & $3.51 \pm 0.005$ & $3.61 \pm 0.008$ & $3.21 \pm 0.005$ \\
\hline ii. 200 & $7.12 \pm 0.015$ & $8.12 \pm 0.017$ & $6.32 \pm 0.008$ \\
\hline
\end{tabular}

*Values are the diameter of zone of inhibition (mean of three replications) in centimeter \pm standard deviation 
Table.2 In vitro efficacy of purified antibacterial proteins (ABP) from CSR 2 silkworm breed against bacterial pathogens

\begin{tabular}{|c|c|c|c|}
\hline \multirow[t]{2}{*}{ Treatments } & \multicolumn{3}{|c|}{ Zone of inhibition (cm \pm S.D. $)^{*}$ by ABP from CSR 2} \\
\hline & E.coli & S.aureus & B.thuringiensis \\
\hline \multicolumn{4}{|c|}{ ABP eluted fractions $(\mu 1)$} \\
\hline \multicolumn{4}{|c|}{ Fraction -7} \\
\hline i. 100 & $2.28 \pm 0.570$ & $2.87 \pm 0.720$ & $1.39 \pm 0.348$ \\
\hline ii. 200 & $2.68 \pm 0.674$ & $2.98 \pm 0.748$ & $1.59 \pm 0.398$ \\
\hline \multicolumn{4}{|l|}{ Fraction -9 } \\
\hline i. 100 & $2.76 \pm 0.693$ & $2.89 \pm 0.720$ & $1.53 \pm 0.383$ \\
\hline ii. 200 & $2.98 \pm 0.748$ & $3.05 \pm 0.764$ & $1.81 \pm 0.448$ \\
\hline \multicolumn{4}{|c|}{ Streptomycin Sulphate } \\
\hline i. 100 & $3.51 \pm 0.005$ & $3.61 \pm 0.008$ & $3.21 \pm 0.005$ \\
\hline ii. 200 & $7.12 \pm 0.015$ & $8.12 \pm 0.017$ & $6.32 \pm 0.008$ \\
\hline
\end{tabular}

$*$ Values are the diameter of zone of inhibition (mean of three replications) in centimetre \pm standard deviation

Table.3 In vitro efficacy of purified antibacterial proteins (ABP) from Double hybrid of Bombyx mori against bacterial pathogens

\begin{tabular}{|l|c|c|c|}
\hline \multicolumn{1}{|c|}{ Treatments } & \multicolumn{3}{c|}{ Zone of inhibition $(\mathbf{c m} \pm$ S.D.)* by ABP from } \\
Double hybrid
\end{tabular}

* Values are the diameter of zone of inhibition (mean of three replications) in centimeter \pm standard deviation

The present results on antibacterial activity of antibacterial protein isolated from B.mori is in line with the findings of Pandia rajan et al.( 2011) who reported that cocoon shell extract had antimicrobial activity against E. coli, Bacillus cereus, S. aureus, Pseudomonas aeruginosa and Klebsiella pneumoniae.

Abraham et al. (1995) reported induction of antibacterial activity in the haemolymph of silkworm by injection with live cells of E.coli which was purified as antibacterial protein by Sephadex G-100 column chromatography, exhibited antibacterial activity against both E.coli and M. luteus.

The present result on antibacterial activity of $\mathrm{ABP}$ against bacterial pathogens were supported with the findings of Sharma et al. (2000) who reported the effectiveness of 
proteins in inhibiting the growth of $P$. aeruginosa (AC-3) and also attributed that low molecular weight proteins were found to be effective against them; the diameter of the inhibition zone was found to be $3.5 \mathrm{~cm}$.

In conclusion, proteins extracted from haemolymph of mulberry silkworm breeds, Rong daizo, CSR2 and double hybrid immunized with bacterial pathogens, Escherichia coli ( $\mathrm{K}^{\mathrm{R}}$ strain), Bacillus thuringiensis and Staphylococcus aureus showed antibacterial activity through inhibition zone assays. Antibacterial activity was found to be higher against E.coli and S.aureus compared to B.thuringiensis for all the breeds studied. The lower efficacy might be due to higher virulence of B.thuringiensis. Thuss exploring the mechanism of induction of antibacterial proteins upon immunization of silkworm breeds with E.coli and S.aureus may pave way for development of disease tolerant breeds.

\section{References}

Abraham, E.G., J. Nagaraju, D. Salunke, H.M. Gupta and R.K. Datta.1995. Purification and partial characterization of induced antibacterial protein in the silkworm, Bombyx mori. Journal of Invertebrate Pathology, 65: 17-24.

Boman, H.G. and D. Hultmark. 1987. Cell- free immunity in insects. Ann.Rev. Microbiol., 41: 103-126.

Boman, H.G., I. Faye, G.H. Gudmundsson, J.J. Lee and D.A. Lidholm. 1991. Cell-free immunity in Cecropia. A model system for antibacterial proteins. Eur. $J$. Biochem., 201: 23-31.
Hara, S., K. Taniai, Y. Kato and M. Yamakawa .1994. Isolation and -amidation of the non - amidated from of cecropin D from larvae of Bombyx mori. Comp. Biochem. Physiol., 108B: 303 - 308.

Hoffmann, J.A and C. Hetru. 1992. Insect defenses- Inducible antibacterial peptides. Immunol. Today, 13: 411 - 415.

Sharma J., Archana Yadav, B.G. Unni and M.C. Kalita. 2005. Antibacterial proteins from non-mulberry silkworms against flacherie causing Pseudomonas aeruginosa AC-3. Current Science, 89 (9): 1613-1618.

Krishnaswami, S.1978. Silkworm feeding traits for evaluating the quality of mulberry leaves as influenced by variety, spacing and nitrogen application. Indian J. Seric., 10(1): 79 - 89.

Morishima, I., S. Suginaka, T. Ueno and H. Hirano. 1990. Isolation and structure of cecropins, inducible antibacterial peptides from the silkworm, Bombyx mori. Comp. Biochem. Physiol., 95 B: 551 - 554.

Morishima, I.,S. Sugunaka, T. Bougaki, M. Makoto and T. Ueno. 1988. Induction and partial characterization of antibacterial proteins in the haemolymph of the silkworm, Bombyx mori. Agric. Biol. Chem., 52 (4): 929-934.

Pandiarajan, J., B.P. Cathrin, T. Pratheep and M. Krishnan . 2011. Defense role of the cocoon in the silkworm Bombyx mori L. Rapid Commun. Mass Spectrom. 25(21):3203-3206

Tanaka. H. and Yamakawa. 2011. Regulation of the innate immune responses in the silkworm, Bombyx mori, ISJ, 8: 59-69.

Tu, Y.Z., X.M. Qu and TS. Xu. 1989. Purification and characterization of peptide from Bombyx mori, Sco. China Ser. B., 32: $1072-1081$.

\section{How to cite this article:}

Manimegalai, S., B. Bebitha and Mohanraj, P. 2017. In vitro Efficacy of Antibacterial Proteins from Haemolymph of Silkworm Breeds against Bacterial Pathogens of Mulberry Silkworm, Bombyx mori L. Int.J.Curr.Microbiol.App.Sci. 6(3): 2055-2059. doi: https://doi.org/10.20546/ijcmas.2017.603.234 